„Analecta Cracoviensia” 51 (2019), s. 99-113

DOI: http://dx.doi.org/10.15633/acr.3635

Rev. Marek Kluz

ORCID: 0000-0002-2255-1431

The Pontifical University of John Paul II in Krakow

\title{
The Ecclesiastical Role of The Holy Spirit in the Sacrament of Confirmation in the Teaching of Benedict XVI
}

Baptism constitutes the basic saving event, both in the individual and social dimension of the Christian life. It is part of the Christian initiation which introduces s person into the history of salvation and communion with God and the Church. Deepening and strengthening of all that baptism entails is performed in the sacrament of confirmation. ${ }^{1}$ This also applies to moral obligations. During one of the general audiences Pope Benedict XVI emphasized that "before he does anything, the Christian already possesses a rich and fruitful interior life, given to him or her in the sacraments of baptism and confirmation." ${ }^{2}$ The main moral call resulting from reception of this sacrament is building of the ecclesial community by finding the proper place in the Church and accepting full responsibility for the

1 "The sacrament of Confirmation confirms baptism and pours [...] abundantly upon the Holy Spirit” (Benedykt xvi, Dążcie do wzniosłych ideałów i bądźcie święci! Przemówienie podczas spotkania z młodzieżą, która przyjmuje sakrament bierzmowania (Watykan - 2 czerwca 2012), "L’Osservatore Romano" (wyd. pol.) 33 (2012) nr 7-8, p. 15). Cf. Katechizm Kościoła Katolickiego, Poznań 1994, no. 1233, 1290, 1304, 1306, 1316. Cf. also: J. Królikowski, Umocnienie i dopełnienie chrztu. Z teologii bierzmowania jako sakramentu wtajemniczenia chrześcijańskiego, in: Dzisiejszy bierzmowany. Problemy i wyzwania, red. J. Stala, Kielce 2005, p. 44-45.

2 Benedykt Xvi, Paweł - Duch Święty w naszych sercach. Audiencja generalna (Watykan 15 maja 2007), "L'Osservatore Romano" (wyd. pol.) 28 (2007) nr 3, p. 32. 
fate of the Church. ${ }^{3}$ Formation of the person also aims at accomplishing this objective.

The Holy Spirit that is delivered in the sacrament of confirmation plays a fundamental role in building the community of the Church. ${ }^{4}$ This is recalled by the new pastoral program of the Church in Poland for the years 2017-2019. The most important goal of the two-year program is to bring the faithful to the Church as a community which is directed and strengthened by the Holy Spirit as well as to deepen knowledge regarding confirmation, not only among the candidates for this sacrament, but also among all baptized people. The Holy Spirit who is the soul of the Church, ${ }^{5}$ fills the faithful with new power and enables to act for the spiritual good of the person and the whole ecclesial community. "In this baptism of the Holy Spirit, there is an inseparable personal and community dimension, 'I' of the disciple and 'we' of the Church." Thus, the Holy Spirit, coming in the sacrament of confirmation with His gifts, fulfils a community-making role.

The ecclesiastical role of the Holy Spirit in the sacrament of confirmation sounds strongly in the teaching of Benedict XVI. In his speeches and documents, the Pope repeatedly brought the truth about the special power of the Holy Spirit and His gifts in building the community dimension of the life of the Church. Therefore, in this reflection - based on the allocations of Pope Benedict - the ecclesiastical role of the Holy Spirit coming in the sacrament of confirmation will be presented.

3 Cf. Wprowadzenie teologiczne i pastoralne, in: Obrzędy bierzmowania, red. Komisja ds. Kultu Bożego i Dyscypliny Sakramentów Episkopatu Polski, no. 2. See also: B. Nadolski, Liturgika, cz. 3: Sakramenty. Sakramentalia. Błogosławieństwa, Poznań 1992, p. 76-77; Z. Janiec, Komunikacja sakramentalna $w$ liturgii, "Liturgia Sacra” 13 (2007) nr 1, p. 53; W. Bołoz, Eklezjalne aspekty moralności chrześcijańskiej, Kraków 1992, p. 123.

4 Benedict emphasizes that "by baptism and confirmation we received this gift in a special way" (Benedykt xvi, Kościół obejmuje cały świat. Homilia podczas Mszy świętej w uroczystość Zesłania Ducha Świętego (Watykan - 12 czerwca 2011), "L'Osservatore Romano" (wyd. pol.) 32 (2011) nr 8-9, p. 27).

5 Cf. Benedykt xvi, Obecność Kościoła w historii jest kształtowana przez Ducha Świętego. Modlitwa niedzielna z papieżem (Watykan - 31 maja 2009), "LOsservatore Romano" (wyd. pol.) 30 (2009) nr 7-8, p. 61.

6 Benedykt xvi, Pięćdziesiątnica - chrzest Kościoła. Modlitwa niedzielna z papieżem (Watykan 11 maja 2008), "L'Osservatore Romano" (wyd. pol.) 29 (2008) nr 6, p. 59.

Cf. C. Krakowiak, Przygotowanie do sakramentu bierzmowania. Aspekt pastoralno-liturgiczny, in: Dzisiejszy bierzmowany..., op. cit., p. 150-151. 


\section{Fuller opening up to the Holy Spirit}

Since Confirmation is a special gift of the Holy Spirit, the basic moral obligation is to open up to the presence and action of this Spirit in the Christian life in a more complete way. Therefore, each of the confirmed should be obedient to the Holy Spirit and allow Him to lead him or her. This encouragement was directed by Benedict in the message of the 23rd World Youth Day - Sydney 2008: "Dear young people, today the Holy Spirit also continues to work with power in the Church and His fruits are abundant to the extent that we are ready to open ourselves to His renewing strength. Therefore, it is important for each of us to get to know Him, enter into a relationship with Him and let Him lead through him or her." "By allowing the Holy Spirit to lead, every baptized person can contribute to building of the Church through the charisms that He gives as 'to each is given the manifestation of the Spirit for the common good' (1 Cor 12:7)."' Therefore, opening up to the gift of the Holy Spirit and surrendering to His direction serves the process of building the Church.

On the level of moral life, this opening up to the presence of the Holy Spirit in the man is expressed in a special subordination of human action not only to light but also to the power of the Holy Spirit. This means that the natural human ability to recognize God's call and response to it, i.e. conscience, is now permeated with Truth and Love whose source is the Holy Spirit. Thus, the reality of conscience is related not to the impersonal law, yet to the gift of love which has a personal character. This is the Holy Spirit who is this Personal Love, "is the Person - the Love, the Person - the Gift." of moral life cannot ignore this fundamental truth about the presence of the Holy Spirit in each person who has been given a new life.

Opening up to the Holy Spirit and unity with Him in the moral life does not mean the destruction of human personality, on the contrary - only then a man fully 'possesses Himself'. However, it must not be forgotten that if the Christian receives the beginning of the gifts of the Holy Spirit, His influence on human life is not the irrecoverable quality of this life. A Christian can close

${ }^{8}$ Benedykt XVI, "Duch Święty zstąpi na was, otrzymacie Jego moc i staniecie się moimi świadkami”" $(D z$ 1, 8). Orędzie na xxıII Światowy Dzień Młodzieży (Watykan - 20 lipca 2007), "L'Osservatore Romano" (wyd. pol.) 28 (2007) nr 9, p. 26-27.

9 Benedykt XVI, "Duch Święty zstąpi na was, otrzymacie Jego moc i staniecie się moimi świadkami”" (Dz 1, 8), op. cit., p. 26-27. Cf. Benedykt Xvi, Paweł Apostoł Narodów, Kraków 2008, p. 43-44.

${ }^{10}$ Jan Paweł II, Encyklika Dominum et vivificantem, Poznań 1997, no. 10. 
himself or herself to the action of the Holy Spirit, he or she can oppose Him and 'grieve' Him (cf. 1 Thess 5:19). However, each person who bases his or her life on the action of the Holy Spirit, receives - as it results from the St. John's teachings - not only the power to persevere in fidelity to Christ, yet, at the same time, this person gains confidence that the world that stands in opposition to Christ is wrong. The Holy Spirit - as Jesus says - is supposed to lead to the whole truth (cf. Jn 16:13).

According to Benedict, "Jesus, speaking here about the Holy Spirit, explains to us what the Church is and how the Church should live, to be itself, to be a place of unity and communion in truth. He tells us that acting as Christians does not mean that we close ourselves in our own 'person' but focusing on the whole. It means accepting the whole Church within ourselves, or even better, the inner consent that the Church accepts us. Consequently, when I say, think, act as a Christian, I do not do this by closing myself in my 'I', but I always do it in its entirety, starting from the whole: in this way, the Holy Spirit, the Spirit of unity and truth, can still resound in the hearts and in the minds of people and convince them to meet and accept each other. The Holy Spirit, precisely because He works this way, introduces us to the whole truth which is Jesus, leads us to exploration of this truth, to its understanding: we do not grow in our cognition by closing ourselves in our 'I', but only when we become capable of listening and sharing with others, only in the 'we' of the Church, in the attitude of deep inner humility." ${ }^{12}$

From obedience to the Holy Spirit, acceptance of His gifts, the ability to conceive oneself in a deeper way and understand the sense of one's life arises. "This interior communion with God in the Holy Spirit makes the person understand himself or herself as well as his or her humanity in a new way. This image and God's likeness reflected in a man from the very beginning are fully accomplished [...]. On this path - on the road of such growing which is also a complete discovery of humanity - God approaches the person, penetrates deeper and deeper into the entire human world." ${ }^{13}$

${ }^{11}$ Cf. Benedykt xvi, Adhortacja apostolska Sacramentum caritatis, Tarnów 2007, no. 12; also: Benedykt XVI, Adhortacja apostolska Verbum Domini, Kraków 2010, no. 15; I. Mroczkowski, Duch, który przekonywa świat o grzechu, in: Duch Święty w posłudze Kościoła wobec świata, red. J. Nagórny, J. Gocko, Lublin 1999, p. 132-136.

${ }^{12}$ Benedykt XVI, Duch Święty prowadzi nas ku wyżynom Boga. Homilia podczas Mszy świętej w uroczystość Zesłania Ducha Świętego (Watykan - 27 maja 2012), "L'Osservatore Romano" (wyd. pol.) 33 (2012) $\mathrm{nr} 7-8$, p. 34 .

${ }^{13}$ Jan Paweł II, Encyklika Dominum et vivificantem, op. cit., no. 59. 
According to Pope Benedict, when a new person can be led by the Holy Spirit, he or she does not recognize his or her decisions, deeds and achievements as exclusively his or her personal merits, however, he or she can perceive them in a new dimension, as gracious love of God who calls him or her and gives him of her the strength to respond fully. In this case, God's command and concrete life vocation are not just a 'must,' yet, a gift of sharing with others in God's love. Opening up to the Holy Spirit allows to look at the whole human life as a gift. ${ }^{14}$

\section{Living according to the Spirit and the obligation of giving testimony}

Through the action of the Holy Spirit, the confirmed person is also able to fulfil the great command of the Christ: "Love one another as I have loved you" (Jn 15:12). Each person who possesses the Holy Spirit, is capable and obliged at the same time - to perform works of love towards God and neighbour. ${ }^{15}$ Thanks to the Holy Spirit, Christians can gain the same victory that Christ had on the cross: overcome even hatred and human sin with love.

The Holy Spirit also forms a community of the redeemed, and it is solely thanks to Him that it is possible to understand and co-create human brotherhood: "For we were all baptized by one Spirit [...] so as to form one Body [...]. We were all given the one Spirit to drink" (1 Cor 12:13). One and the same Spirit also gives many different gifts to build one Body - a community of people with Jesus (1 Cor. 12:4-12). Thanks to the gifts of the Holy Spirit, the whole law is fulfilled in this one command: "You shall love your neighbour as yourself" (Ga 5:14). ${ }^{16}$

Through the action of the Holy Spirit, particularly in the sacrament of confirmation, what the prophets announced has been fulfilled: "I will put my law in their minds and write it on their hearts" (Jer 31:31-34). This means that the confirmed who lives according to the gift of grace recognized in him or her, reads all external moral laws - also the positive law of the Gospel and the laws

${ }^{14}$ Cf. Benedykt Xvi, Niech Duch Święty rozpali w nas ogień Bożej miłości. Homilia podczas Mszy świętej w uroczystość Zesłania Ducha Świętego (Watykan - 23 maja 2010), "L'Osservatore Romano" (wyd. pol.) 31 (2010) nr 7, p. 47.

${ }_{15}$ Cf. J. Misiurek, Apostolstwo wyrazem dojrzałości chrześcijańskiej, in: Dojrzałość chrześcijańska, red. A. J. Nowak, W. Słomka, Lublin 1994, p. 114-116 (Homo meditans, 11).

${ }^{16}$ Cf. Benedykt xvi, Encyklika Deus caritas est, Kraków 2006, no. 1, 19. Cf. also: Benedykt Xvi, Encyklika Caritas in veritate, Kraków 2009, no. 5. 
defined by the Church (led by the Holy Spirit) - as an expression of God's love and he or she is trying to implement them. The point is - as Pope Benedict XVI explains - that by the power of the Holy Spirit the Christian would be able to read not only the external moral norm, yet, its deepest meaning, arising from the supernatural endowment. Moreover, to be able for the Christian to accept the divine call included in this norm not by the power of external authority, yet, to interpret this norm to make it an internal imperative. In this sense, St. Paul says that a Christian is liberated from the "letter of the Law" and from the "law of sin" (Rom 8:2). "for the letter kills, but the Spirit gives life" (2 Cor $3: 6)$. This liberation is also caused by the fact that "where the Spirit of the Lord is, there is freedom" (2 Cor 3:17). ${ }^{17}$

A Christian is not deprived of the moral law, but he or she is not "under the law". It is Christ in him or her is his or her law (1 Cor 9:20). However, it should be clearly stated that the Christian, in order to distinguish the true freedom of God's children from false ideas of freedom, needs external legal norms (1 Tim 1:9; Gal 3:19). All of this ultimately gives rise to the ability of the person to recognize in himself or herself all the basic dimensions of his or her existence in a deeper way. ${ }^{18}$

The Holy Spirit who also calls to fulfil the command of Christ: "You shall be my witnesses" (Acts 1:8) descends in the sacrament of Confirmation. "The Spirit sanctifies the person - said Benedict XVI in consideration before the prayer Angelus - and at the same time He makes the person a living member of the mystical Body of Christ, a participant in the mission of witnessing to His love. This is accomplished through the Sacraments of Christian initiation: Baptism and Confirmation." ${ }^{19}$ Therefore, the life of the confirmed person should be directed at giving public testimony of faith, hope and love. This testimony will be particularly strong when the person binds himself or herself and reveals it in a spirit of unity and brotherhood with the Church. ${ }^{20}$

Christ, while calling to the apostolate, simultaneously making people capable of it, providing with the gifts of the Holy Spirit and charisms in the

${ }^{17}$ Cf. Benedykt xvi, Modlitwa wyzwala. Audiencja generalna (Watykan - 16 maja 2012), "L'Osservatore Romano" (wyd. pol.) 33 (2012) nr 6, p. 44.

${ }^{18}$ Cf. J. Stala, Sakrament bierzmowania w świetle dokumentów synodalnych Kościoła w Polsce po 1980 roku, in: Dzisiejszy bierzmowany..., op. cit., p. 77-8o.

19 Benedykt Xvi, Pięćdziesiątnica - chrzest Kościoła, op. cit., p. 59.

${ }^{20}$ Cf. C. Bartnik, Bierzmowanie Kościoła, “CollectaneaTheologica” 48 (1978), p. 27-30. Cf. also: M. Kowalczyk, Eklezjalno-apostolski charakter bierzmowania, “Communio" 12 (1992) nr 2, p. 93-99. 
sacrament of confirmation. Pope Benedict XVI reminded about this in the Sacramentum Caritatis: "The gifts of the Holy Spirit are given for building of the Body of Christ (1 Cor 12) and for giving a greater, evangelical testimony in the world." ${ }^{21}$ Similarly, Pope Benedict Xvi said in the homily to candidates for confirmation: "The Sacrament of Confirmation confirms the Sacrament of Baptism and pours the abundance of the gifts of the Holy Spirit in you. Now, you who are filled with gratitude have the opportunity to receive His great gifts that will help you become faithful and courageous witnesses of Jesus in on the way of life. The gifts of the Holy Spirit constitute a wonderful reality that will allow you to form yourself as Christians, live according to the Gospel and be active members of the community." ${ }^{22}$

Therefore, the Christian is a person strengthened in his or her vocation, gifted to the mission of apostolate in the Church and in the world. The confirmed person is supposed to be a witness to Christ and His love. This testimony about Christ should take place in each environment. In Him we fulfil our Christian mission. $^{23}$

However, giving testimony to Christ is - above all - to take place in our own family, called the "home church." ${ }^{24}$ Preparation for marriage should become an opportunity to recall and realize the above obligation, arising from the received sacrament of confirmation. Also, the family as a whole is also obliged to apostolate. Certainly, this requires a lot of patience, the ability to withstand the hardships of everyday life and problems resulting from living in the community. Yet, the Holy Spirit, given in confirmation, teaches how to overcome all obstacles and leads us along the path of unselfish love. This is confirmed by Benedict XVI in one of the Sunday homilies: "The Holy Spirit enlightens the human spirit, and by revealing the crucified and risen Christ, indicates where we can become like Him, i.e. be 'an expression and an instrument of love which emanates from Him (Deus caritas est, 33)."

${ }^{21}$ Benedykt XVI, Adhortacja apostolska Sacramentum caritatis, op. cit., no. 17.

${ }^{22}$ Benedykt xvi, Dążcie do wzniostych ideałów i bądźcie święci!, op. cit., p. 15.

${ }^{23}$ Cf. J. Misiurek, Apostolstwo wyrazem dojrzałości chrześcijańskiej..., op. cit., p. 107-122; K. Jeżyna, Sakrament Bierzmowania źródłem nowej ewangelizacji, "Roczniki Teologiczne” 51 (2004) z. 3, p. 79-9o.

${ }^{24}$ Jan Paweł II, Adhortacja apostolska Familiaris consortio, Częstochowa 1991, no. 21, 52, 54, 59, 61, 86. Cf. also: Katechizm Kościoła Katolickiego, op. cit., no. 1656.

${ }_{25}$ Benedykt xvi, Tajemnica miłości naszego Boga. Homilia podczas Mszy świętej w uroczystość Zesłania Ducha Świętego (Watykan - 4 czerwca 2006), "L'Osservatore Romano" (wyd. pol.) 27 (2006) nr 8, p. 13. 
Love is the greatest gift of the Holy Spirit - the Spirit of love and unity. Although a Christian receives this gift in the holy baptism, he or she is strengthened and is subject to growth in the sacrament of confirmation. The sacrament of confirmation shapes mature, responsible love that desires love for the good of others. The desire to make other people happy is the greatest human ability, hence love is the highest value. However, without the Holy Spirit, it is not possible to fulfil the command of love, since - as Benedict Xvi claims in Deus caritas est - the Spirit reveals Himself as the inner power that harmonises the human heart with the heart of Christ and enables him or her to love his or her brothers as He loved them. ${ }^{26}$ "The Spirit is also the power that transforms the heart of the Church community to be a worldly witness of the love of the Father who wants to make humanity one family in His Son."27

\section{The task of sanctifying oneself and one's neighbours}

In the sacrament of confirmation, the Christian is invited and called to cooperate with Christ and the Holy Spirit on gaining moral perfection or sanctity more closely. A seal embossed in the soul by the Sanctifying Spirit should become the norm of life and the motive of such an action. ${ }^{28}$ Pope Benedict repeatedly encouraged the candidates for the sacrament of confirmation follow the path of holiness courageously. In one of the homilies he shouted: "Dear young people, I am telling you with power: aim at the great ideals, be holy! But is it possible to be a saint at your age? I will answer you: of course! St. Ambrose, the great saint of your city, also talks about this in one of his works: 'each age is mature for Christ' (De virginitate, 40). Above all, this is confirmed by the testimony of your many saint peers, such as Dominik Sawio or Maria Goretti. Holiness is the ordinary way of the Christian: it is not reserved for the very few chosen, but it is open to all. Certainly, thanks to the light and power of the Holy Spirit!"29 Sanctification, sanctity means the life led on the basis of received grace, it means dedication to God the Sanctifier. As the Holy Spirit constantly

${ }^{26}$ See Benedykt XVI, Encyklika Deus caritas est, op. cit., no. 19. See also: Sobór Watykański II, Dekret o posłudze i życiu prezbiterów Presbyterorum ordinis, in: Sobór Watykański II, Konstytucje, dekrety, deklaracje, Poznań 2008, no. 5; Katechizm Kościoła Katolickiego, op. cit., no. 1303-1305.

${ }^{27}$ Benedykt Xvi, Encyklika Deus caritas est, op. cit., no. 19. Cf. Benedykt Xvi, List apostolski Porta fidei, Kraków 2012, no. 10.

${ }^{28}$ Cf. F. J. Rosato, Wprowadzenie do posoborowej teologii sakramentów, tłum. A. Baron, Kraków 1998 , p. $62-65$.

${ }_{29}$ Benedykt Xvi, Dążcie do wzniosłych ideałów i bądźcie święci!, op. cit., p. 16. 
works in those who have received His gifts, the sanctifying task is dynamic and it is carried out throughout life. Hence, the author of Revelation (Apocalypse) exclaims: "Let the holy one be sanctified" (Rev 22:11).

However, the confirmed person who is sanctified in the Christ should not only think of sanctity of the Self in a selfish way. A true Christian should realize that there cannot be personal perfection without genuine solidarity with the whole community, particularly with the neighbours as well as the material world (infrahumanum). Each person who has already received the first gifts of the Spirit should devote himself or herself with all his or her strength to fulfil his or her mission in this world, his or her professional life and his or her community. In this way, the entire apostolate of lay people ${ }^{30}$ and commitment of the Christian in the world receive both deepest and religious character and contribute to building the Church as a common home in a significant way. ${ }^{31}$

Thanks to the Holy Spirit, the confirmed person also has effective means to overcome a sin which is also an evil against the supernatural community which is the Church - the Mystical Body of Christ. It is a kind of rebellion against the Head of the same Body and - at the same time - an evil against the good of the members of this community. "St. Paul - Benedict XVI teaches lists the deeds of the body - there are sins of selfishness and violence, such as: hostility, dispute, envy, discord; these are thoughts and actions that do not allow to live in a truly human and Christian way in love. This is the direction that leads to loss of life. The Holy Spirit, on the other hand, leads us to the heights of God so that we may live on this earth, the seed of God's life that is in us." 33

People marked with baptism and confirmation, thus belonging to Christ and His Church in a special way, if they sin, they cease to be a sign of faith for those who are outside the Church, and for co-religionists - they are not support and strengthening on the common path of vocation. What is more, through their sins they cause that the work of the Church, the entire supernatural community of believers, is less transparent in the dimension of witness and less effective in the dimensions of bringing salvation to the world. Therefore, the sin of a Christian has a harmful effect taking into account ecclesiastical

3o Cf. wider: Sobór Watykański II, Dekret o apostolstwie świeckich Apostolicam actuositatem, in: Sobór Watykański II, Konstytucje, dekrety, deklaracje, op. cit., no. 2-33.

${ }^{31}$ Benedykt XVI, "Duch Święty zstąpi na was, otrzymacie Jego moc i staniecie się moimi świadkami”" (Dz 1,8), op. cit., p. 27-28.

${ }^{32}$ Cf. I. Mroczkowski, Duch, który przekonywa świat o grzechu..., op. cit., p. 131-149.

${ }^{33}$ Benedykt Xvi, Duch Święty prowadzi nas ku wyżynom Boga, op. cit., p. 35. 
and social dimension. It is a contradiction of the law of love which should lie at the foundation of the life of the community of God's people. Thought this, it destroys the mutual brotherhood between people; the sinner is guided by purely utilitarian motives, without taking into consideration the effects of his or her sinful act. It contributes to the exchange of service due to God and neighbour for slavery of sin and Satan. ${ }^{34}$ Therefore, it is the Christian's duty to stand in the truth in front of oneself, i.e. see his or her sins, admit to evil and realize that God, the Church and the whole community are hurt through a sin. The complete awareness of $\sin$ in the person that always destroys unity with God and other people can lead to the path of reconstruction of broken relationships and the path of love. The fruitful acceptance of the sacrament of confirmation allows the person to become a mature Christian. ${ }^{35}$

\section{Care about the formation of candidates for confirmation}

Reception of the Holy Spirit and His gifts in the confirmation is - at the same time - an important stage in preparing the young person to choose and undertake the life vocation. Therefore, it is necessary prepare for its reception in the proper way. ${ }^{36}$ The Exhortation Familiaris consortio reminds that these are mostly parents who are obliged to prepare their children for the sacrament of confirmation. Parents "involve children through a gradual Christian initiation into the Body - Eucharistic and ecclesiastical - of Christ, they become parents in full, not only the parents of physical life, but also of the life which through rebirth of the Holy Spirit, flows from the Cross and Resurrection of Christ." ${ }^{37}$ Parents as catechists through the testimony of life, prayer and catechesis form the temple of the Holy Spirit in their children..$^{88}$

In preparation for confirmation, parents teach their children to be open to the Holy Spirit and adopt the attitude of service to others. Parents should help their children receiving the sacrament of confirmation to maintain

${ }^{34}$ Cf. Greniuk, Grzech - nawrócenie - pokuta, in: Być chrześcijaninem dziś. Teologia dla szkót średnich, red. M. Rusecki, Lublin 1992, p. 314-315.

${ }_{35}$ Cf. G. Bernacki, Bierzmowanie sakramentem chrześcijańskiej dojrzałości, in: Dojrzałość chrześcijańska, op. cit., p. 43.

${ }^{36}$ Cf. Kodeks prawa kanonicznego, Poznań 1984, kan. 890.

37 Jan Paweł II, Adhortacja apostolska Familiaris consortio, op. cit., no. 39.

${ }^{38}$ Cf. Benedykt xvi, Modlitwa i sakramenty dają nam światło prawdy. Homilia wygłoszona podczas Mszy świętej w Niedzielę Chrztu Pańskiego (Watykan - 8 stycznia 2012), "L'Osservatore Romano" (wyd. pol.) 33 (2012) nr 2, p. 25-27. 
a constant and living relationship with the Holy Spirit. John Paul II expresses it as follows: "Confirmation, dear young people, introduces you to the age of Christian maturity [...]. And your families who are enjoying this great stage of their lives with joy today, will consider this not only to be their duty, but the privilege of helping you to maintain a constant, faithful and vivid awareness of the importance of your encounter with the Holy Spirit." 39 Parents and godparents are - in some sense - special 'confidants' of the gifts of the Holy Spirit. In this way, they teach their children to live in the community and raise them to the choice of the proper calling.

Priests help in preparation for fruitful reception of the sacrament of confirmation as well. ${ }^{40}$ "To those of you - Pope Benedict wrote in his address to the XXIII World Youth Day - Sydney 2008 - who have not received the sacrament of Confirmation yet, I am sending a cordial invitation to prepare for its reception, asking your priests for help. This is a special moment of grace that the Lord offers to you: do not let it escape!"41 It is worth noting that in the situation of school catechesis there is a danger of alienation of young people from the parish life. Therefore, the system of preparation for confirmation taking place in the parish community is of special value. This preparation, through formation, experience and prayer, helps young people to become aware of the need to participate in the life of the parish, gives the opportunity to participate in the formation of this basic religious community as well as it allows to enter the universal dimension of the Christ Church through parish and take responsibility for it. ${ }^{42}$

\section{Summary}

In the reflection of Pope Benedict XVI, confirmation is the sacrament of special responsibility for the Church. Confirmation strengthens dynamism of baptismal grace and gives the special power of the Holy Spirit, preparing for undertaking of apostolic activity and it connects with the Church is a closer

39 Cf. Benedykt xvi, Modlitwa i sakramenty daja nam światło prawdy, op. cit., p. 25-27.

${ }^{40}$ Cf. C. Krakowiak, Wychowanie do świadomości chrzcielnej, "Liturgia Sacra" 13 (2007) nr 2, p. $354-358$.

${ }_{41}$ Benedykt XVI, "Duch Święty zstąpi na was, otrzymacie Jego moc i staniecie się moimi świadkami" (Dz 1, 8), op. cit., p. 27.

${ }^{42}$ Cf. J. Styrna, Wstęp, in: "Na przyjęcie Ducha Świętego". Przygotowanie do bierzmowania we wspólnocie parafialnej, red. W. Burek, B. Klaus, Tarnów 1995, p. 8-9. 
way. The obligation to live actively and in accordance with the Spirit in the Church and for the Church results from the fact of full membership in the Church. The confirmed person receives gifts and specific tasks for building the community of the whole Church from the Holy Spirit. Life in the Christ cannot be fulfilled outside of the Church since this is the Mystical Body of the Christ. Faithful and responsible fulfilment of all obligations arising from the sacrament of baptism significantly determines development of the sacramental personality of the person. Thus, we can see that the sacrament of confirmation brings specific moral obligations related to care for development of the Church and implementation of the Christian vocation. However, the solid formation is necessary for the person in order not to waste the graces resulting from the sacrament of confirmation. Only the genuine and solid formation can make the Christian participate in a in the essence and mission of the Church in a conscious way, accepting the sacramental style of life coming from confirmation and encouraging to implement the evangelical values in the society.

\section{ABstract}

Formation of an ecclesial community constitutes the basic moral call arising from reception of the sacrament of confirmation. Formation of the person should also aim at accomplishing this objective. The Holy Spirit given in the sacrament of confirmation plays a fundamental role in building the Church. Opening up to the gift of the Holy Spirit and submission to His direction allows to find the proper place in the Church and accept full responsibility for destiny of the Church.

The ecclesiological role of the Holy Spirit in the sacrament of conformation sounds significantly in the teaching of Benedict XVI. In his speeches and documents, the Pope repeatedly brought the truth about the special power of the Holy Spirit and His gifts into building the community dimension of the life of the Church. Therefore, in this reflection - based on allocations of Pope Benedict XVI - the ecclesiological role of the Holy Spirit, coming in the sacrament of confirmation, was presented.

\section{KEYWORDS}

Benedict XVI, preaching, sacrament of confirmation, the Holy Spirit, Church, testimony, holiness, love 


\section{Abstrakt \\ Eklezjotwórcza rola Ducha Świętego w sakramencie bierzmowania w nauczaniu Benedykta XVI}

Duch Święty dany w sakramencie bierzmowania odgrywa fundamentalną rolę w budowaniu Kościoła. Otwartość na dar Ducha Świętego i poddanie się Jego kierownictwu pozwala znaleźć właściwe miejsce w Kościele i przyjąć pełną odpowiedzialność za jegp przeznaczenie. Eklezjotwórcza rola Ducha Świętego w sakramencie bierzmowania jest znaczącym elementem w nauczaniu Benedykta Xvı.

\section{BIBLIOGRAPHY}

Bartnik C., Bierzmowanie Kościoła, "Collectanea Theologica" 48 (1978), p. 19-30. Benedykt XVI, Adhortacja apostolska Sacramentum caritatis, Tarnów 2007.

Benedykt XVI, Adhortacja apostolska Verbum Domini, Kraków 2010.

Benedykt Xvi, Dążcie do wzniosłych ideałów i bądźcie święci! Przemówienie podczas spotkania $z$ młodzieża, która przyjmuje sakrament bierzmowania (Watykan 2 czerwca 2012), "L'Osservatore Romano" (wyd. pol.) 33 (2012) nr 7-8, p. 15-16.

Benedykt Xvi, Duch Święty prowadzi nas ku wyżynom Boga. Homilia podczas Mszy świętej w uroczystość Zesłania Ducha Świętego (Watykan - 27 maja 2012), "L'Osservatore Romano" (wyd. pol.) 33 (2012) nr 7-8, p. 33-35.

Benedykt XVI, "Duch Święty zstapi na was, otrzymacie Jego moc i staniecie się moimi świadkami” (Dz 1,8). Orędzie na XXIII Światowy Dzień Młodzieży (Watykan 20 lipca 2007), "L’Osservatore Romano" (wyd. pol.) 28 (2007) nr 9, p. 25-28.

Benedykt XVI, Encyklika Caritas in veritate, Kraków 2009.

Benedykt Xvi, Encyklika Deus caritas est, Kraków 2006.

Benedykt XVI, Kościół obejmuje cały świat. Homilia podczas Mszy świętej w uroczystość Zesłania Ducha Świętego (Watykan - 12 czerwca 2011), "L'Osservatore Romano" (wyd. pol.) 32 (2011) nr 8-9, p. 26-27.

Benedykt XVI, List apostolski Porta fidei, Kraków 2012.

Benedykt Xvi, Modlitwa i sakramenty dają nam światło prawdy. Homilia wygłoszona podczas Mszy świętej w Niedzielę Chrztu Pańskiego (Watykan - 8 stycznia 2012), "L'Osservatore Romano" (wyd. pol.) 33 (2012) nr 2, p. 25-27.

Benedykt xvi, Modlitwa wyzwala. Audiencja generalna (Watykan - 16 maja 2012), "L'Osservatore Romano" (wyd. pol.) 33 (2012) nr 6, p. 43-44.

Benedykt Xvi, Niech Duch Święty rozpali w nas ogień Bożej miłości. Homilia podczas Mszy świętej w uroczystość Zesłania Ducha Świętego (Watykan - 23 maja 2010), "L’Osservatore Romano" (wyd. pol.) 31 (2010) nr 7, p. 47-48. 
Benedykt Xvi, Obecność Kościoła w historii jest kształtowana przez Ducha Świętego. Modlitwa niedzielna z papieżem (Watykan - 31 maja 2009), "L'Osservatore Romano" (wyd. pol.) 30 (2009) nr 7-8, p. 61.

Benedykt XVI, Paweł Apostoł Narodów, Kraków 2008.

Benedykt Xvi, Paweł - Duch Święty w naszych sercach. Audiencja generalna (Watykan - 15 maja 2007), "L'Osservatore Romano" (wyd. pol.) 28 (2007) nr 3, p. 31-32. Benedykt XVI, Pięćdziesiątnica - chrzest Kościoła. Modlitwa niedzielna z papieżem (Watykan - 11 maja 2008), "L'Osservatore Romano" (wyd. pol.) 29 (2008) nr 6, p. 59. Benedykt Xvi, Tajemnica miłości naszego Boga. Homilia podczas Mszy świętej w uroczystość Zesłania Ducha Świętego (Watykan - 4 czerwca 2006), "L'Osservatore Romano" (wyd. pol.) 27 (2006) nr 8, p. 12-13.

Bernacki G., Bierzmowanie sakramentem chrześcijańskiej dojrzałości, w: Dojrzałość chrześcijańska, red. A. J. Nowak, W. Słomka, Lublin 1994, p. 37-44 (Homo meditans, 11).

Bołoz W., Eklezjalne aspekty moralności chrześcijańskiej, Kraków 1992.

Greniuk F., Grzech - nawrócenie - pokuta, w: Być chrześcijaninem dziś. Teologia dla szkót średnich, red. M. Rusecki, Lublin 1992, p. 311-320.

Jan Paweł II, Adhortacja apostolska Familiaris consortio, Częstochowa 1991.

Jan Paweł II, Bierzmowanie zobowiązuje nas do apostolstwa. Homilia podczas udzielania sakramentu bierzmowania (Imola - 9 maja 1986), "L'Osservatore Romano" (wyd. pol.) 7 (1986) nr 5, p. 13, 16.

Jan Paweł II, Encyklika Dominum et vivificantem, Poznań 1997.

Janiec Z., Komunikacja sakramentalna $w$ liturgii, "Liturgia Sacra" 13 (2007) nr 1, p. $47-58$.

Jeżyna K., Sakrament bierzmowania źródłem nowej ewangelizacji, "Roczniki Teologiczne" 51 (2004) z. 3, p. 79-9o.

Katechizm Kościoła Katolickiego, Poznań 1994.

Kodeks prawa kanonicznego, Poznań 1984.

Kowalczyk M., Eklezjalno-apostolski charakter bierzmowania, “Communio” 12 (1992) nr 2, p. 92-102.

Krakowiak C., Przygotowanie do sakramentu bierzmowania. Aspekt pastoralno-liturgiczny, in: Dzisiejszy bierzmowany. Problemy i wyzwania, red. J. Stala, Kielce 2005, p. $143-180$.

Krakowiak C., Wychowanie do świadomości chrzcielnej, "Liturgia Sacra" 13 (2007) nr 2, p. 341-368.

Królikowski J., Umocnienie i dopełnienie chrztu. Z teologii bierzmowania jako sakramentu wtajemniczenia chrześcijańskiego, in: Dzisiejszy bierzmowany. Problemy $i$ wyzwania, red. J. Stala, Kielce 2005, p. 35-52. 
Misiurek J., Apostolstwo wyrazem dojrzałości chrześcijańskiej, in: Dojrzałośćchrześcijańska, red. A. J. Nowak, W. Słomka, Lublin 1994, p. 107-122 (Homo meditans, 11).

Mroczkowski I., Duch, który przekonywa świat o grzechu, w: Duch Święty w postudze Kościoła wobec świata, red. J. Nagórny, J. Gocko, Lublin 1999, p. 131-149.

Nadolski B., Liturgika, cz. 3: Sakramenty. Sakramentalia. Błogosławieństwa, Poznań 1992.

Rosato F. J., Wprowadzenie do posoborowej teologii sakramentów, tłum. A. Baron, Kraków 1998.

Sobór Watykański II, Dekret o apostolstwie świeckich Apostolicam actuositatem, in: Sobór Watykański II, Konstytucje, dekrety, deklaracje, Poznań 2008, p. 580-629.

Sobór Watykański II, Dekret o posłudze i życiu prezbiterów Presbyterorum ordinis, in: Sobór Watykański II, Konstytucje, dekrety, deklaracje, Poznań 2008, p. 747-805. Stala J., Sakrament bierzmowania w świetle dokumentów synodalnych Kościoła w Polsce po 1980 roku, in: Dzisiejszy bierzmowany. Problemy i wyzwania, red. J. Stala, Kielce 2005, p. 77-93.

Styrna J., Wstęp, in: "Na przyjęcie Ducha Świętego". Przygotowanie do bierzmowania we wspólnocie parafialnej, red. W. Burek, B. Klaus, Tarnów 1995, p. 7-11.

Wprowadzenie teologiczne i pastoralne, in: Obrzędy bierzmowania, red. Komisja ds. Kultu Bożego i Dyscypliny Sakramentów Episkopatu Polski, Katowice 2003, p. 3-8. 